\title{
The molecular-genetic and phylogenetic analysis of the hemaglutinin gene of influenza viruses
}

\author{
O. Yu. Smutko ${ }^{1,2}$, L. V. Radchenko², A. Yu. Fesenko², O. S. Holubka ${ }^{2}$, \\ I. G. Budzanivska1 ${ }^{1}$, A. P. Mironenko ${ }^{2}$ \\ ${ }^{1}$ Educational and Scientific Center "Institute of Biology and Medicine", \\ Taras Shevchenko National University of Kyiv \\ 64/13, Volodymyrska Str., Kyiv, Ukraine, 01601 \\ ${ }^{2}$ Gromashevsky L. V. Institute of Epidemiology and Infection Diseases, NAMS of Ukraine \\ 5, Amosova Str., Kyiv, Ukraine, 03038 \\ oksanasmutko@gmail.com
}

\begin{abstract}
Aim. To perform a phylogenetic and molecular-genetic analysis of the HA genes of influenza viruses that circulated in Ukraine during the 2016-2017 epidemic season, and to compare them with those that circulated in the world. Methods. Samples (nasopharyngeal swabs from patients) were analyzed using the real-time polymerase chain reaction (RT-PCR). Phylogenetic trees were constructed using MEGA 7 software. 3D structures were constructed in Chimera 1.11.2rc software. Results. Ukrainian isolates from the 2016-2017 season have substitutions in the antigenic sites which were not detected earlier; they and can influence the antigenic properties of viruses. Otherwise the $\mathrm{A}(\mathrm{H} 3 \mathrm{~N} 2)$ and $\mathrm{B} /$ Victoria viruses retained the similarity to the vaccine strains. For the A(H1N1)pdm09, a higher similarity to the vaccine strain recommended for the 2017-2018 epidemic season was observed. Conclusions. In the 2016-2017 epidemic season, all influenza viruses - A(H3N2), A(H1N1)pdm09 and B/Victoria acquired a number of unique amino-acid substitutions in the HA gene. The results of this study reaffirm the continuous genetic variability of circulating seasonal influenza viruses and the need for continued systematic antigenic and molecular surveillance.
\end{abstract}

Ke y w o r d s: influenza viruses, hemagglutinin, antigenic site, mutation.

\section{Introduction}

Influenza viruses cause global epidemic infections each year, a peak is from December to March. These pathogens have also contributed to six global pandemics known so far. Influenza viruses are a group of pathogens in the family Orthomyoviridae, which are classified into 6 genera (A,B,C, Thogotovirus, Isavirus and new unnamed genus). Type A influenza viruses are categorized based on their surface glycoproteins: hemagglutinin (HA) and neur-

(C) 2018 O. Yu. Smutko et al.; Published by the Institute of Molecular Biology and Genetics, NAS of Ukraine on behalf of Biopolymers and Cell. This is an Open Access article distributed under the terms of the Creative Commons Attribution License (http://creativecommons.org/licenses/by/4.0/), which permits unrestricted reuse, distribution, and reproduction in any medium, provided the original work is properly cited 
aminidase (NA). So far 17 HA and 9 NA subtypes have been identified [1]. Hemagglutinin is known to be a major target region of neutralizing antibodies which inhibit binding with sialic acid receptors effectively. Mutations in the $\mathrm{HA}$ antigenic sites designated A, B, C, D, and $\mathrm{E}$ in IAV of $\mathrm{H} 3 \mathrm{~N} 2$ subtype, may result in strains which can escape recognition by preexisting neutralizing antibodies [2]. It is known that the H1 HA molecules have four distinct antigenic sites: $\mathrm{Sa}, \mathrm{Sb}, \mathrm{Ca}$, and $\mathrm{Cb}$ [3]. Influenza viruses $\mathrm{B} /$ Victoria have four antigenic sites - 120-loop, 150-loop, 160-loop and 190-helix [5]. As a result, these sites consist of the most variable amino acids in the HA molecule of the seasonal human $\mathrm{H} 1 \mathrm{~N} 1$ viruses that have been subjected to antibodymediated immune pressure (antigenic sites H1). Gradual accumulation of mutations at these sites is noted to be an integral component of evolutionary dynamics and impacts viral survival and fitness. This evolutionary mechanism, known as antigenic drift, is the basis for frequent updating of the composition of seasonal influenza vaccines [4]. The World Health Organization (WHO) encourages National Influenza Centers (NICs) to conduct ongoing influenza virologic surveillance, to monitor spread of viruses and their continuous evolution. Combining data from phylogenetic and molecular analyses of influenza viruses is essential to detect virus variants that have undergone antigenic drift, variants with enhanced virulence or variants with reduced sensitivity to antivirals. Such combined genetic, antigenic and phylogenetic analyses provide improvements in the process of vaccine virus selection and inform patient treatment regimens [5].

\section{Methods}

Nasal-throat swabs were taken from the patients with suspected influenza and SARI (severe acute respiratory infections). Samples were analyzed using a real-time polymerase chain reaction (RT-PCR). Influenza viruses were isolated in MDCK and MDCK-SIAT cell culture. The isolates were later used for the strain identification and sequencing.

The sequencing of influenza viruses isolates was performed in the World Influenza Center in London using the technology of RNA-SEQ. The sequences of influenza viruses from other countries were received from web-site GISAID (the Global Initiative on Sharing All Influenza Data - http://platform.gisaid.org) using BLAST analysis. The sequences were aligned using ClustalW algorithm. Phylogenetic trees were built by the neighbor joining method applying Kimura 2-parameter model. The nucleotide sequences were translated into the amino acid sequences using MEGA 7 software [6]. 3D structures were constructed in Chimera 1.11.2rc software (https://www.cgl.ucsf.edu/ chimera/).

\section{Results and Discussion}

Influenza viruses type A: A(H1N1)pdm09 and $\mathrm{A}(\mathrm{H} 3 \mathrm{~N} 2)$; and influenza viruses type $\mathrm{B}$, lineage $\mathrm{B} /$ Victoria were circulated during 20162017 epidemic season.

The epidemic season of 2016-2017 years was less intensive than the previous epidemic season of 2015-2016 years. In Ukraine $\mathrm{A}(\mathrm{H} 3 \mathrm{~N} 2)$ viruses played a main role in this season, as well as in other European countries. According to the Ministry of Health of Ukraine, in the 2016-2017 season 30 fatal cases of influenza were registered, while in the previous 
season this figure was 10 times higher [7]. In total in the 2016-2017season, according to the official statistics, only 106,753 persons were vaccinated against the flu, $15 \%$ less than in the previous season. HA gene sequences were recovered from GISAID and phylogenetic trees were constructed to determine the genetic relationships of Ukrainian isolates with the reference viruses and viruses circulating in other countries in the same period. Complete HA amino acid sequences of Ukrainian influenza isolates were compared to those of the vaccine viruses to identify substitutions that might impact the vaccine effectiveness.

\section{Characterization of mutations of influ- enza viruses type A(H3N2)}

The HA genes fell within genetic group 3C. This group has three subdivisions: 3C.1, 3C.2 and 3C.3; subdivisions 3C.2 and 3C.3 have undergone further evolution to yield subclades designated as 3 C.2a, 3C.3a and 3 C. $3 \mathrm{~b}$ respectively. New subclade 3C.2a1 was emerged in the last 2016-2017 epidemic season. All viruses belonged to the genetic group 3C.2a1 had acquired amino acid substitutions N171K, I406V and G484E (I77V and G155E in HA2) [7] (Fig. 1). The majority of Ukrainian isolates belonged to a new genetic group 3C.2a1. Only three isolates belonged to the genetic group 3C.2a. The mutation N128T resulting in gain of glycosylation site was in the antigenic site B. This is one of the options for defending the virus from immune protection of the human body. Some of mutations can influence the antigenic properties of viruses as they are found in the antigenic sites. The mutation in 144 position is located in the antigenic site A, two mutations 159 and 160 - in the antigenic site $\mathrm{B}$, position 311 - in the antigenic site $\mathrm{C}$ [3]. None of the substitutions in HA relate to known MDCK culture-induced substitutions [8]. The viruses from the group 3C.2a.1 were similar to the isolates from New York, Cyprus, Florida and Ontario. The influenza viruses $\mathrm{A}(\mathrm{H} 3 \mathrm{~N} 2)$ from the group 3C.2a.1 retain similarity to the vaccine strain $\mathrm{A} / \mathrm{Hong}$ Kong/4801/2014, so the emerged mutations in new group 3C.2a.1 apparently did not affect the antigenic properties of the virus. The strain A/Hong Kong/4801/2014 was recommended for the vaccine composition for the next 20172018 epidemic season.

\section{Characterization of mutations of influ- enza viruses type B, lineage B/Victoria}

Phylogenetic comparison of the influenza virus type B HA genes has shown that all investigated isolates are genetically related to the vaccines strain B/Brisbane/60/2008 (Fig. 2).

Currently among the viruses of influenza $\mathrm{B}$ the genetic branch B / Victoria the strains belonging to the genetic group $1 \mathrm{~A}$ are circulating in the world [9]. All these isolates have specific mutations, which attached these isolates to the $1 \mathrm{~A}$ group. On the phylogenetic tree of the gene of $\mathrm{HA}$, two reference isolates belong to the genetic group $1 \mathrm{~B}$, but now these isolates are not circulating in the world.

The comparison of molecular-genetic changes was carried out with the reference strain B/Malaysia/2506/2004. All the viruses had mutations N75K, N165K, S172P, and I199T comparing with the reference strain (Fig.2). The mutations N165K and I119T are placed in the antigenic site of 160-loops and 190-helix respectively. The accumulation of such mutations in the antigenic sites leads to 
the changes in the antigenic properties of viruses [5].

Several mutations were in the antigenic sites: I117V and N129D - in 120-loop antigenic site, V146I - in 150-loop antigenic site. Ukrainian isolates were similar to the viruses from different parts of the World. Despite the mutations, the viruses retained genetical similarity to the vaccine strain $\mathrm{B} / \mathrm{Brisbane} / 60 / 2008$ at $99 \%$ and strain $\mathrm{B} / \mathrm{Brisbane} / 60 / 2008$ was recommended for the vaccine composition for the next 2017-2018 epidemic season [9].

\section{Characterization of mutations of influ- enza viruses type A(H1N1)pdm09}

The percentage of pandemic influenza viruses was the smallest in the epidemic 2016-2017 season. Only two A(H1N1) viruses were isolated in Ukraine - from Kharkiv and Odesa. The viruses isolated in Ukraine in the 20152016 season belong to the 6B genetic group, which has two new subgroups 6B.1 and 6B.2 that emerged this season. All viruses belonged to the genetic group 6B.1 in the 2016-2017 season. The amino acid sequence analysis was performed in comparison with the vaccine strain A/California/07/2009. This strain was in the vaccine composition since 2009 , and only according to the recommendation for the 2017-2018 epidemic season it was replaced by a new one [9]. Ukrainian viruses isolated in the 2016-2017 epidemic season belonged to new genetic group 6B.1 and were related to the viruses from Maldives and England. It may indicate the place of origin of Ukrainian viruses. The $\mathrm{S} 162 \mathrm{~N}$ main substitution appeared in the Sa antigenic site and was observed in all isolates of the 6B.1 genetic group, and this mutation influenced the antigenic properties of viruses [7]. That is why in the recommendation for the 2017-2018 epidemic season the vaccine strain was replaced by a new one - A/ Michigan/45/2015, which belongs to the new genetic subgroup 6B.1 [9].

All viruses had mutations - D97N, S185T, and S124N (HA2), K163Q, A256T, K283E. The mutation in position 185 was in the antigenic site $\mathrm{Sb}$. The S185T substitution falls within a domain defining the receptor binding site (RBS). It has been reported that substitutions in or near the RBS can influence the antigenic properties of $\mathrm{A}(\mathrm{H} 1 \mathrm{~N} 1)$ pdm09 viruses [10], and attachment of oligosaccharide chains to the antigenic sites has been suggested to facilitate the immune evasion. None of these substitutions were associated with known adaptation to propagation in MDCK culture [11].

The $\mathrm{A}(\mathrm{H} 1 \mathrm{~N} 1) \mathrm{pdm} 09$ viruses isolated in Ukraine in 2016-2017 belonged to the new genetic group and were similar to the strain A/ Michigan/45/2015. It was recommended as a vaccine strain for the next 2017-2018 epidemic season. The group 6B.1 influenza viruses are expected to dominate next season.

\section{Conclusions}

The 2016-2017 influenza season was less intense in both the number of cases and the number of deaths compared to the 2015-2016 season in Ukraine. This season also differed by the main virus: it was the strain $\mathrm{A} / \mathrm{Hong}$ Kong/4801/2014 A(H3N2), which we expected as the main causative agent of the epidemic in 2016-2017. This strain was included in the influenza vaccines. We expect a medium level of epidemic in the next 2017-2018 season in Ukraine. The main virus may be A/ 


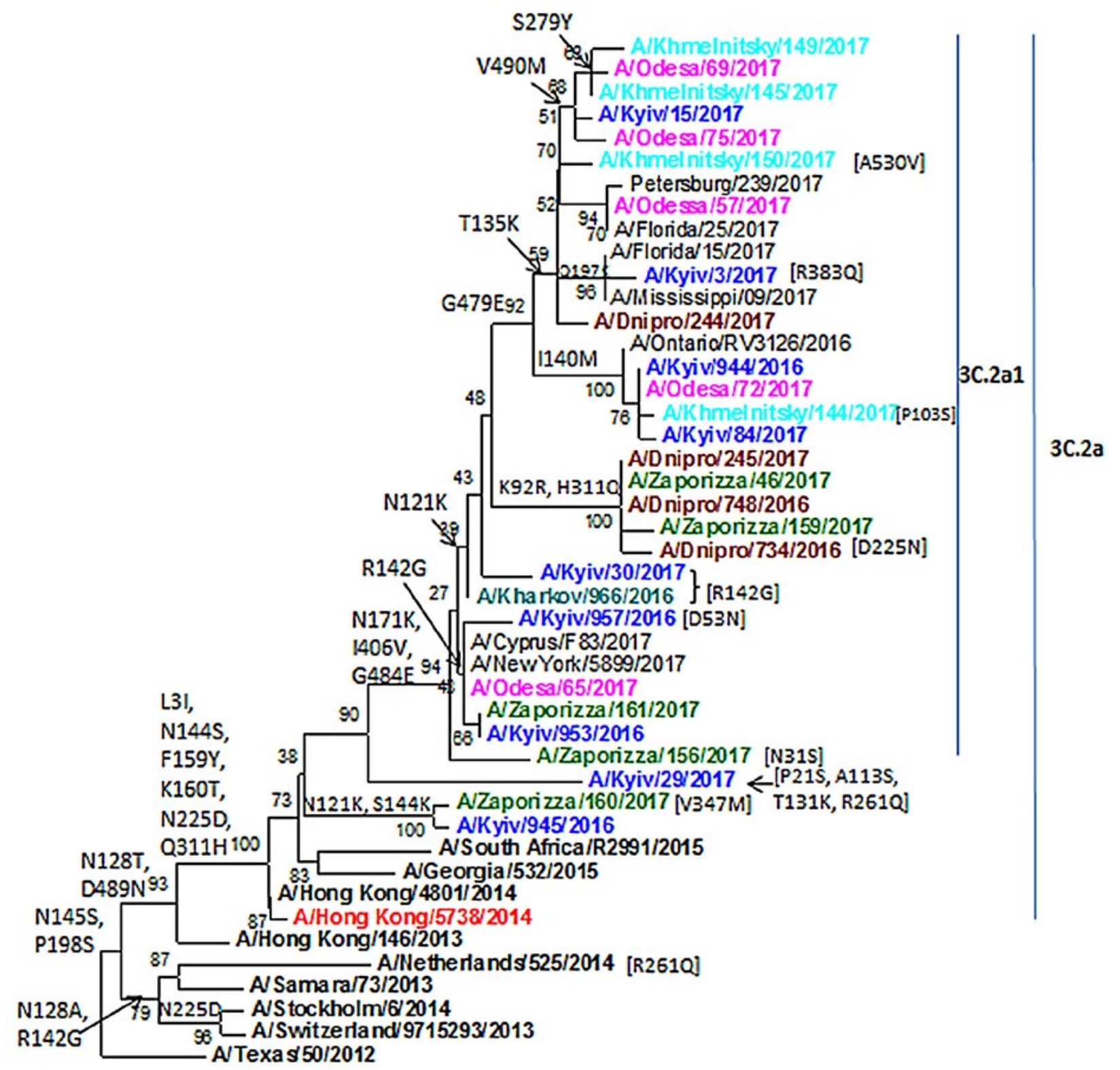

Fig.1. Phylogenetic comparison of A(H3N2) influenza virus of the 2016-2017 season in terms of hemagglutinin (HA) nucleotide sequences carried out by NJ (neighbor-joining) method, and Kimura 2-parameter model, with 1000 bootstrap replications.

Fig.2. Phylogenetic comparison of the B/Victiria influenza virus of the 2016 - 2017 season in terms of hemagglutinin (HA) nucleotide sequence carried out by NJ (neighbor-joining) method, and Kimura 2-parameter model, with 1000 bootstrap replications. 


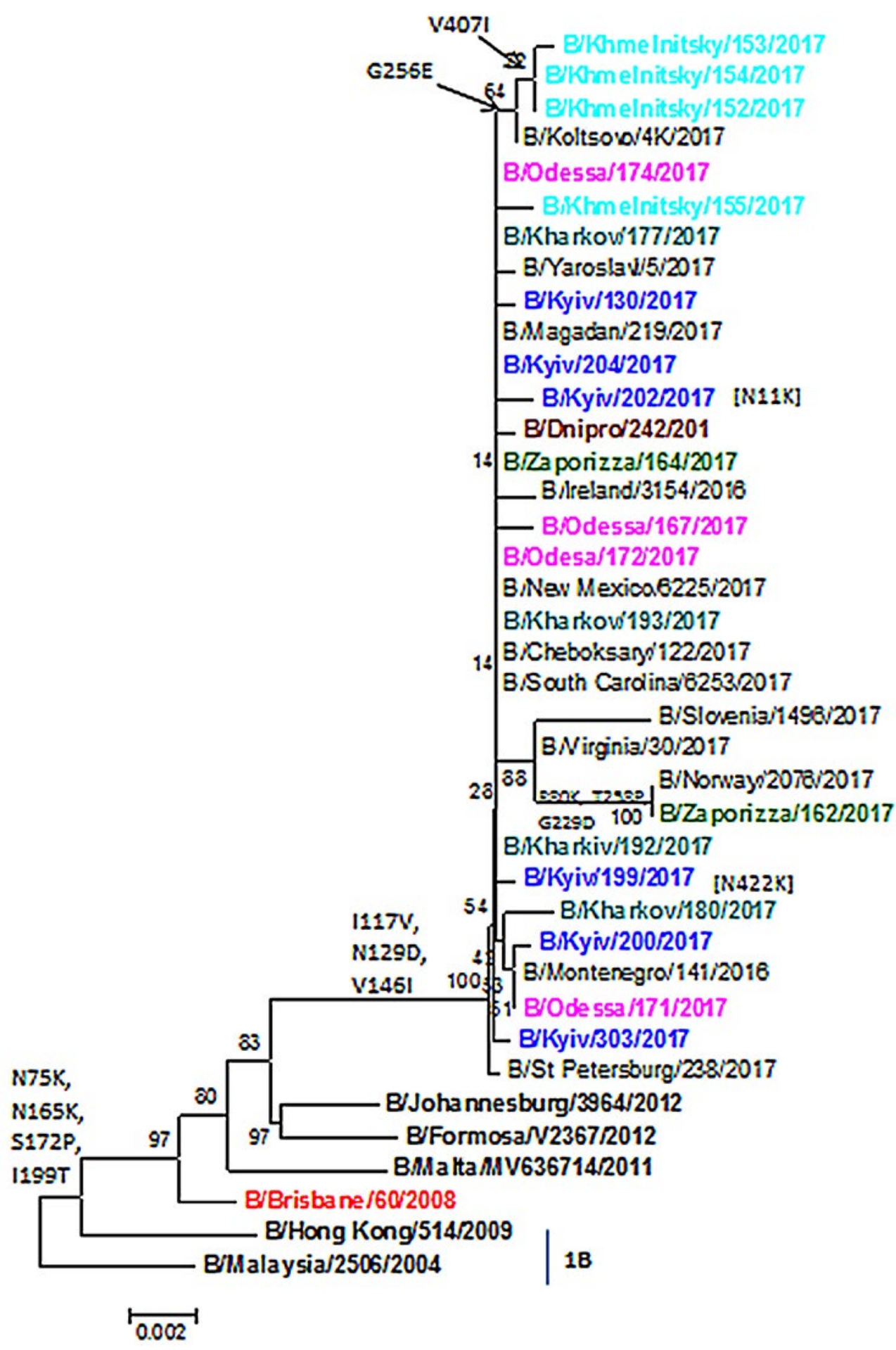




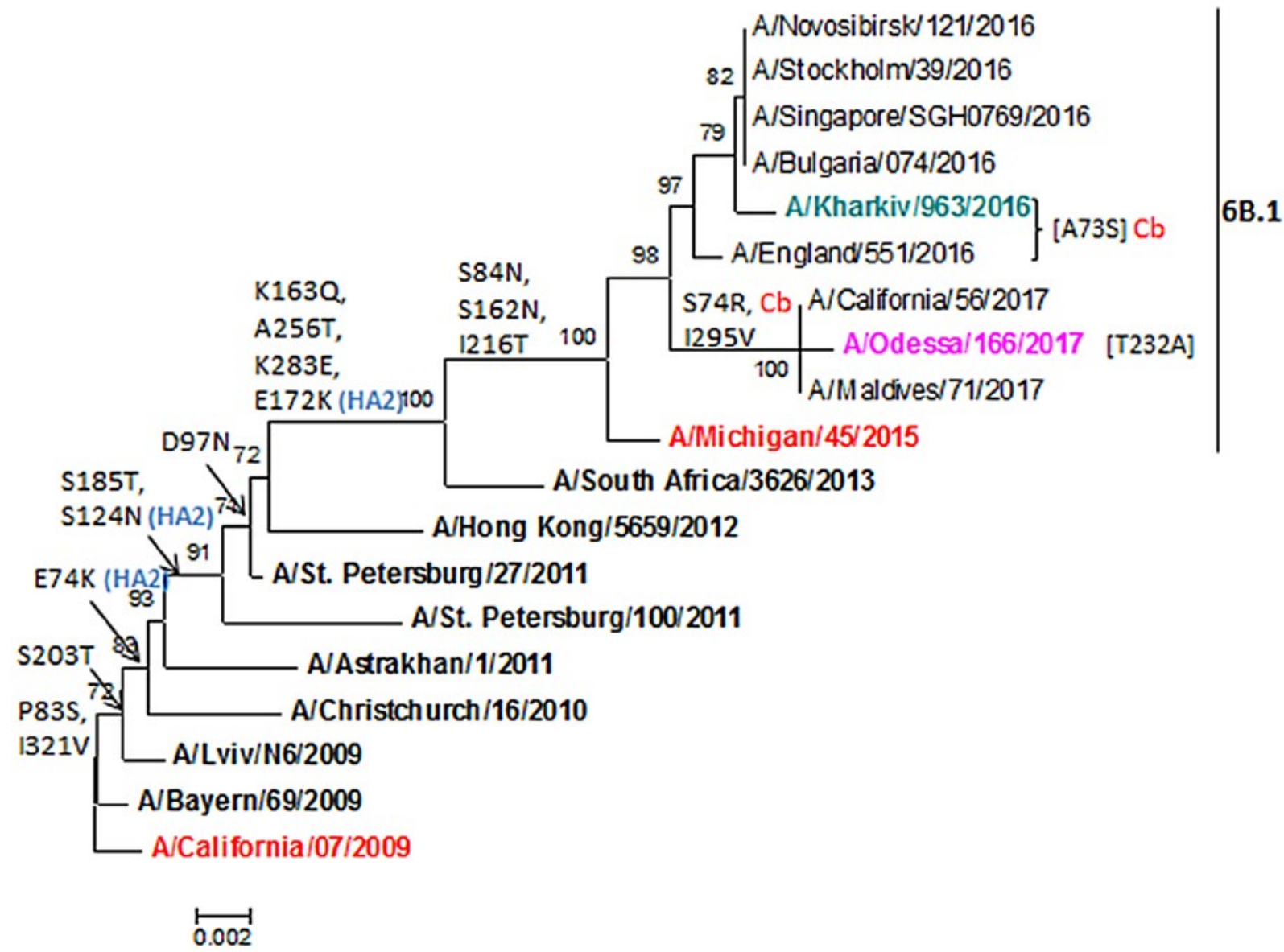

Fig. 3. Phylogenetic comparison of A(H1N1)pdm09 influenza virus of the 2016- 2017 season in terms of hemagglutinin (HA) nucleotide sequences carried out by NJ (neighbor-joining) method, and Kimura 2-parameter model, with 1000 bootstrap replications.

Michigan/45/2015 (H1N1)pdm09, which belong to the new genetic group.

In the $2016-2017$ epidemic season, the $\mathrm{A}(\mathrm{H} 3 \mathrm{~N} 2), \mathrm{A}(\mathrm{H} 1 \mathrm{~N} 1) \mathrm{pdm} 09$ and B/Victoria influenza viruses acquired a number of unique amino-acid substitutions in the HA gene. Ukrainian isolates have substitutions in the antigenic sites, which emerged in the previous and 2016 - 2017 seasons not being detected before, and can influence the antigenic prop- erties of viruses. Despite this, the viruses $\mathrm{A}(\mathrm{H} 3 \mathrm{~N} 2)$ and $\mathrm{B} /$ Victoria retained the similarity to the vaccine strains. For A(H1N1)pdm09 a higher similarity was observed to the vaccine strain A/Michigan/45/2015 for the 2017-2018 epidemic season than to A/California/07/2009.

New for Ukraine strain A / Michigan / $45 / 2015$ of pandemic influenza viruses $\mathrm{A}(\mathrm{H} 1 \mathrm{~N} 1)$ pdm09 may become the leading cause of the next epidemic in the country. The 
B/Brisbane/60/2008 (B/Victoria lineage) and A/Hong Kong/4801/2014 (A (H3N2)) strains are not new and are unlikely to cause significant epidemic discomfort next season.

\section{REFERENCES}

1. ECDC working group on influenza A(H1N1)v. Preliminary analysis of influenza $\mathrm{A}(\mathrm{H} 1 \mathrm{~N} 1) \mathrm{v}$ individual and aggregated case reports from EU and EFTA countries. Euro Surveill. 2009;14(23):19238.

2. Anton A, Pozo F, Niubo J, Casas I, Pumarola T. Influenza A(H1N1)pdm09 virus: viral characteristics and genetic evolution. Enferm Infecc Microbiol Clin. 2012; 30(Supp 4):10-17.

3. Igarashi $M$, Ito K, Yoshida R, Tomabechi D, Kida H, Takada $A$. Predicting the antigenic structure of the pandemic (H1N1) 2009 influenza virus hemagglutinin. PLoS One. 2010;5(1):e8553. doi:

4. Ann J, Papenburg J, Bouhy X, Rhéaume C, Hamelin MÉ, Boivin $G$. Molecular and antigenic evolution of human influenza A/H3N2 viruses in Quebec, Canada, 2009-2011. J Clin Virol. 2012;53(1):88-92.

5. Korsun N, Angelova S, Gregory V, Daniels R, Georgieva I, McCauley J. Antigenic and genetic characterization of influenza viruses circulating in Bulgaria during the 2015/2016 season. Infect Genet Evol. 2017;49:241-250.

6. Kumar S, Stecher G, Tamura K. MEGA7: Molecular Evolutionary Genetics Analysis Version 7.0 for Bigger Datasets. Mol Biol Evol. 2016;33(7):1870-4.

7. Mironenko AP, Holubka OS, Smutro OY, Radchenko LV, Fesenko AY. The Results of the Influenza Epidemic Season in Ukraine in 2016-2017 and forecast for the next season 2017-2018. Klin Immunol, Allergol, Infectol. 2017; 5(102):5-8.

8. Lee HK, Tang JW, Kong DH, Loh TP, Chiang DK, Lam TT, Koay ES. Comparison of mutation patterns in full-genome A/H3N2 influenza sequences obtained directly from clinical samples and the same samples after a single MDCK passage. PLoS One. 2013;8(11):e79252.

9. World Health Organization. Recommended composition of influenza virus vaccines for use in the 2016 southern hemisphere influenza season. Weekly Epidemiological Record. 2015; 90,(41):545-60.

10. Koel BF, Mögling R, Chutinimitkul S, Fraaij PL, Burke DF, van der Vliet $S$, de Wit E, Bestebroer TM, Rimmelzwaan GF, Osterhaus AD, Smith DJ, Fouchier $R A$, de Graaf $M$. Identification of amino acid substitutions supporting antigenic change of influenza A(H1N1)pdm09 viruses. $J$ Virol. 2015;89(7):3763-75.

11. Ramadhany R, Yasugi $M$, Nakamura $S$, Daidoji $T$, Watanabe Y, Takahashi K, Ikuta K, Nakaya T. Tropism of pandemic 2009 H1N1 influenza a virus. Front Microbiol. 2012;3:128.

\section{Молекулярно-генетичний та філогенетичний аналіз гену гемаглютиніну вірусів грипу}

О. Ю. Смутько, Л. В. Радченко, А. Ю. Фесенко, О. С. Голубка, І. Г. Будзанівська, А. П. Міроненко

Мета. Провести філогенетичний та молекулярно-генетичний аналіз генів НА вірусів грипу, що циркулювали на території України протягом епідемічного сезону 2016-2017 років та порівняти їх з тими, що циркулювали в світі. Методи. Зразки (назофаригіальні змиви від паціентів) були проаналізовані методом полімеразної ланцюгової реакції в реальному часі (3ТПЛР). Філогенетичні дерева будували в програмі MEGA7. 3D структури будували в програмі Chimera 1.11.2rc. Результати. Українські ізоляти мали заміни в антигенних сайтах, що виникли в попердніх сезонах та епідемічному сезоні 2016-2017 років і не виявлялись раніше, які можуть мати вплив на антигенні властивості вірусу. Не дивлячись на це, віруси грипу А(H3N2) та B/Victoria зберегли подібність до вакцинних штамів. Для вірусів грипу A(H1N1)pdm09 була показана вища подібність до вакцинного штаму, рекомендованого на епідемічний сезон 2017-2018 років. Висновки. В епідемічному сезоні 2016-2017 років всі віруси грипу A(H3N2), A(H1N1)pdm09 та B/Victoria набули значну кількість унікальних амінокислотних заміщень в гені гемаглютиніну. Результати цього дослідження підтверджують постійну генетичну мінливість циркулюючих вірусів сезонного грипу та необхідність постійного систематичного антигенного та молекулярного нагляду. 
К л юч о в і с л о в а: віруси грипу, гемаглютинін, антигенний сайт, мутації.

\section{Молекулярно-генетический и филогенетический анализ гена гемагглютинина вирусов гриппа}

О. Ю. Смутько, Л. В. Радченко, А. Ю. Фесенко, О. С. Голубка, И. Г. Будзанивская,

А. П. Мироненко

Цель. Провести филогенетический и молекулярно-генетический анализ генов НА вирусов грипа, которые циркулировали на территории Украины в эпидемическом сезоне 2016-2017 годов и сравнить их с теми, что циркулировали в мире. Методы. Образцы (назофаригиальные смывы от пациентов) были проанализированы методом полимеразной цепной реакции в реальном времени (ОТ-ПЦР). Филогенетические деревья строили в программе MEGA7. 3D структуры строили в программе Chimera 1.11.2rc. Результаты. Украинские изоляты имели замены в антигенных сайтах, возник- шие в предыдущих сезонах и эпидемическом сезоне 2016-2017 годов и не выявлялись ранее, которые могут повлиять на антигенные свойства вируса. Несмотря на это, вирусы гриппа A (H3N2) и B / Victoria coxpaнили сходство с вакцинными штаммами. Для вирусов гриппа A (H1N1) pdm09 было показано сходство с вакцинным штаммом, рекомендованным на эпидемический сезон 2017-2018 годов. Выводы. В эпидемическом сезоне 2016-2017 годов все вирусы гриппа A(H3N2), A(H1N1)pdm09 и B/Victoria приобрели значительное количество уникальных аминокислотных замещений в гене гемагглютинина. Результаты этого исследования подтверждают постоянную генетическую изменчивость циркулирующих вирусов сезонного гриппа и необходимость постоянного систематического антигенного и молекулярного надзора.

К л юч е в ы е с л о в а: вирусы гриппа, гемагглютинин, антигенный сайт, мутации.

Received 15.01.2018 